\title{
Bridging Black Male and Female Standpoints through Autoethnographic Cultural Symbiosis in Gloria Naylor's The Men of Brewster Place
}

\section{Adishree Vats}

PhD Research Scholar, School of Languages and Literature, SMVD University, Kakryal, Jammu, India; Assistant Professor, Department of English Studies, Akal University, Talwandi Sabo, Bathinda, Punjab, India. Email: vatsadishree8@gmail.com

\begin{abstract}
:
The present paper argues that Gloria Naylor in The Men of Brewster Place (1998) spectacularly recreates, from black female's viewpoint, a solemn literary leeway for African American men's narratives, and recommends an obligatory shufti to their hidden lives as to how the apparatuses of dominion objectify, suppress and marginalize African American men as well. These men have also been victimized, marginalized and objectified on the basis of their race, class and sexuality by the stereotypical mainstream power structure just like their female counterparts. Furthermore, the paper endeavours to scrutinize how it is unworkable to accomplish a genuine Black Feminist Standpoint without essentially appreciating Black Men's Standpoint. Black men, who although are suppressors when it comes to their relationship with black females, but simultaneously, are also being suppressed beneath the tutelage of mainstream hegemonistic-cum-stereotypical power system. As a sequel to Naylor's first novel, The Women of Brewster Place (Naylor, 1983), The Men of Brewster Place attempts to autoethnographically lend some voice to her male characters, who complemented her female characters in the first novel.
\end{abstract}

KEYWORDS: Black Men's Standpoint, Black Feminist Standpoint, Autoethnography, Exploitation, Racism, Classism, Sexism.

\section{INTRODUCTION:}

A meticulous assessment of Black women's literature underscores the verity that African American men have always been characterized negatively. This is precisely explicated by Edward M. Jackson in his book, Images of Black Men in Black Women Writers 1950-1990 (Jackson, 1992), referring to the unconstructive pessimism in the portrayal of African American men, particularly citing examples of Maya Angelou and Alice Walker. He further

This Open Access article is published under a Creative Commons Attribution Non-Commercial 4.0 International License (http://creativecommons.org/licenses/by-nc/4.0/), which permits non-commercial re-use, distribution, and reproduction in any medium, provided the original work is properly cited. For citation use the DOI. For commercial re-use, please contact editor@rupkatha.com. 
mentions that "positive image of black males are the exceptions, rather than the rule" (Jackson 22). In the similar vein, Delgado and Stefancic advocate that Black masculinity is "the social construction of men of colour is even more troublesome and confining than that of men in general" (Delgado and Stefancic 211). Similarly, Johnson and McCluskey adumbrate that black men have always been negatively stereotyped as "uncivilized and subhuman ......[and] sex obsessed" (Johnson and McCluskey, 1997), escalating their grapples for a normal manhood. The probable justification of this unconstructive stereotyping can be that African American females believe that their male counterparts fail to recognize their wrestles based on gender discrimination inside their own black community.

Furthermore, even the contemporary statistical studies (2016) in the U.S. show that black men, for whom racial impartiality remains an indescribable aim, are unjustly and unlawfully treated across various spheres of life: "black people are treated less fairly in the workplace..., when applying for a loan or mortgage..., in dealing with the police..., in the courts..., in stores or restaurants..., when voting in elections..., lower quality schools...and lack of jobs." ("On Views of Race and Inequality", 2016) This passage affirms how African American men toil assiduously in recovering and upholding their identities in a society dipped in racial discrimination. Gloria Naylor, in her novel The Women of Brewster Place (Naylor, 1983), though participates in the portrayal of patriarchal-cumhegemonistic dominance of black men, but later, while conversing with Toni Morrison, she attempts to substantiate her unconstructively pessimistic depiction by adumbrating that:

"[T]here was something that I was very self-conscious about with my first novel; I bent over backwards not to have a negative message come through about the men. My emotional energy was spent creating a woman's world, telling her side of it because I knew it hadn't been done enough in literature. But I worried about whether or not the problems that were being caused by the men in the women's lives would be interpreted as some bitter statement I had to make about black man." (Naylor and Morrison 23)

Through the aforementioned elucidation, Naylor justifies her use of unconstructive representation of her male characters as a corollary of their exhibition of stereotypically sexist as well as male-dominated actions while negotiating with their female counterparts, and this scenario has been lucidly outlined in The Women of Brewster Place. Naylor eventually realizes how both African American men and women are inseparable in terms of racial and sexist oppression. All the male characters like Basil, Eugene, Jerome, C. C. Baker, Moreland Woods or Cliff Jackson, "despite their intrinsic limitations and follies" (Kannan 788), are found to "struggle hard, attempt to establish their identity, and make their presence powerfully felt by dint of their doggedness and self-styled approach to life even in con-fronting failures, misfortunes and disappointments" (Kannan 788). This 
synchronic occurrence of being a suppressor and suppressed concurrently is also brilliantly outlined by Gloria Wade-Gayle in her work, No Crystal Stair: Visions of Race and Sex in Black Women's Fiction (Gayles, 1984), in which she articulates the omnipresence of racism and classism in black men's lives as well. She triumphantly employs the imagery of three-circles to explicitly outline the luminal conditionality of African American men:

"There are three major circles of reality in American society, which reflect degrees of power and powerlessness. There is a large circle in which white people, most of them men, experience influence and power. Far away from it there is a smaller circle, a narrow space, in which black people, regardless of sex, experience uncertainty, exploitation and powerlessness. Hidden in this second circle is a third, a small, dark enclosure in which black women experience pain, isolation, and vulnerability. These are the distinguishing marks of black womanhood in white America." (Gayles 3-4)

The above-mentioned passage aptly indicates towards the sum and substance of dichotomy in terms of authority, supremacy, and positionality of African American males in the social structure. Although these men exploit their women counterparts on the basis of sexism, they are themselves getting exploited by racial bigotry. This altercation based on the fact that even the patriarchal dominance exercised by them does not permit these African American men any access to the mainstream world, makes them realize their dual positionality in the society administrated by whites.

\section{Black Autoethnographic Analysis of the Text:}

The first foretaste of transformation and the formation of bond amongst the African American men, in the novel, The Men of Brewster Place, emanates from their shared space of marginality in Brewster Place. In this context, Jackie Thomas, while reviewing the novel, adumbrates that "[a]ll of these men have unique situation that tie them to Brewster Place. The gift piano player, Brother Jerome, captures the plight of all black men of Brewster place through his playing of the blues, Although he is labelled a 'retarded child', he is the silent, brilliant force that is able to put things together through his music" (Thomas, 2017). This adumbration exemplifies how Jerome's music becomes the only source of reassurance and comfort for the men in the oppressive mainstream hegemonistic world. These men identify themselves with Jerome's tunes as if "[h]is music is telling us [them] about our [their] lives" (Naylor, The Men of Brewster Place 37). The appealing thing about his singing is that he presents the dilemmas and predicaments of African American men in the white suppressive community

Another foretaste of transformation which intensifies the bond amongst the males in Brewster Place is the symbolic representation of barbershop. For them, it becomes "the only place for us men to get together, to look into each other's eyes and see what we 
need to see-that we do more than just exist-we thrive and we are alive" (Naylor, The Men of Brewster Place 167). It is Jackie Thomas, to whom, this barber shop appears as a potential space for African American men. He demonstrates that "the barbershop is the place where all the Black men come to be themselves and to discuss their lives and society. They discuss their present conditions vent their frustrations and dream about more promising future" (Thomas, 2017). The barbershop further exemplifies how these African American men transform their place of despotism into place of confrontation, ultimately helping them to autoethnographically construct their own standpoint..

In the novel, The Men of Brewster Place, the so-called stereotypical-cumpatriarchal black men mentioned in Naylor's first novel, are provided with a second opportunity to elucidate themselves. The first character acting as an epitome of tyrannical oppression is Ben, the janitor of Brewster Place, for whom Maxine Lavon Montgomery avers that "his history of injustice, anger, powerlessness, and despair offers a historical frame for the contextualization of the stories the other men relate" (Montgomery, "Review" 176-178). Brutally slaughtered by a flustered girl Lorraine, the rape-victim in Naylor's first novel, Ben is resuscitated in The Men of Brewster Place as a raconteur. There is duality in the representation of his character, as he is, on one hand, nothing more than a disconnected bystander, and on the other, the one who aggressively accomplices in the intricately multifaceted adversities of black males. His narrative "allows an insight into the deep seated anger in the black men that emanates from their condition of helplessness, partially because of his wife's inclination towards mainstream white culture and partially because of his socio-economic conditions" (Kumar, African American Literature 182).

Approximating the afflictions of his grandfather, a sharecropper by profession, once a slave, who fails to shield his female sibling from the viciousness of sexual exploitation, Ben also finds himself deficient in protecting his own daughter from the similar animalistic brutality by the hands of Mr. Clyde, his landlord. Here black men's autoethnographic convictions permit us to understand how Ben's mutedness bears an account of powerlessness and social-cum-economic abuse by the authoritative mainstream stereotypical America. Ben's vulnerability goes to an extent where he even fails to explain his daughter's exploitation to his wife, Elvira, living in a pseudo-American dream and always chasing money. His story further accentuates upon the suppressed rage that compels Ben to take refuge into alcoholism. His narrative ultimately underscores the dilemmas and predicaments faced by African American men - their silent afflictions waiting for heavenly vengeance for all the racial malfeasances.

The next striking character is of Brother Jerome, an autistic retard, yet whose narrative indicates how artistically genius he is when he plays the blues on his piano. His is the only account that does not bear any association with Naylor's first novel, The Women of Brewster Place. Jerome's narrative underscores how the identification of his masculinity is associated with the playing of his wobbly standing grand piano, whose 
misplaced keys as well as unstable cords explode to life once he begins to play them. Seeing her son's talent as a spring of fiscal gains, the self-gratifying Mildred decides to charge for each of Jerome's performances. Nevertheless, his music is seen articulating for each African American male, lending voice to their aggravations and despondencies, as well as symbolizing their expeditions for self-worth and self-admiration.

Not just Ben and Jerome, we find Basil also narrating the accounts of his subjectivization and marginalization. In The Women of Brewster Place, we have seen Basil escaping from bail, ultimately leaving Mattie, his mother, to sacrifice their home which she had kept as mortgage. He provides no alternative for Mattie except moving to Brewster Place as he himself says, "[t]he only thing I did know--for a fact--is that she ended up on Brewster Place, just like the rest, 'cause she had no choice. And she stayed for the same reason" (Naylor, The Men of Brewster Place 42). A meticulous scrutiny of his narration underscores how Basil escapes his bail as a consequence of his disbelieve in the mainstream judicial structure as well as its attitude towards African American men, and this further elucidates the subjectivization of these males in the capitalist America:

"The state nails me for involuntary manslaughter. Some high-priced lawyer my mother hired said, Don't worry, a clean record, no prior arrests, they'll dismiss the charges. Sure, for white men like him--no charges. But the court already had my butt in jail with bail set at an outrageous five hundred thousand. Ten percent down, said the bail bondsman. The only thing she had was her home--free and clear-after thirty years. So her hundred percent went into their ten percent. And if I could have believed in the system the way she did, I wouldn't have run." (Naylor, The Men of Brewster Place 45).

The above-mentioned passage from the text elucidates how Basil too, like Mattie, is objectified and exploited by the domineering structures of the mainstream bureaucracy. So, as repentance for all the destitutions his mother had to go through because of him, he decides to start his own family and shower all his love to his two kids- Jason and Eddie. He aspires to salvage them from the objectification, marginalization and victimization by the authoritative hands of the stereotypical racial structure as well as from the prevailing socio-economic circumstances.

The next character portrayal is of Eugene's, Lucielia's spouse, who, in The Women of Brewster Place, is known for deceiving, and eventually leaving his sincere and vulnerable wife. In Naylor's previous work, we see Eugene scuffling with Lucielia, and in that moment, losing sight of his little daughter Serena. Consequently, unguarded and unattended, Serena puts a fork in the electric socket, thereby dying of electrocution. In the novel, The Men of Brewster Place, Naylor effectively portrays his narrative version of that unfortunate day. A meticulous analysis of his narrative underscores how, basically, Eugene is victimized by his own sexuality, where the sexist power system of the 
mainstream America obliges him to disguise himself in what Adrienne Rich calls "compulsory heterosexuality" (Rich, Compulsory Heterosexuality, 1981). Eugene's situation provokes the stereotypical world view to amend the customs of the domineering social order that habitually considers homosexuality as nothing more than an anomalous commotion. However, despite his intense sexual orientations, he endeavours to make his marriage work: "I would go home, kiss you hello, and then go into the bathroom to put my head down and cry" (Naylor, The Men of Brewster Place 83). Out of the fear of what his wife and other might think of him, Eugene decides to adopt a twofold-identity, which ultimately smashes to smithereens his own individuality This fear of societal acceptability does not permit Eugene to divulge his sexual orientation to his wife, thereby deteriorating his condition, which eventually results in Eugene losing both his wife and daughter. Naylor, here, effectively displays Eugene's suicidal thoughts, through the voice of Ben, at the time of his daughter's funeral:

"He was grieving too hard to accept that the child was dead. And I knew that his was the kind of grief that could swallow the whole world--himself included--if you let it get out of hand. I saw suicide in that boy's eyes and I prayed for him to get a grip on things. Just let the pain and the regrets wash over you; you won't drown although you'll feel like you will. No, the one fact about regrets is that they do ebb in time and you're faced with the hard decision to let your life go on or not." (Naylor, The Men of Brewster Place 162)

A black autoethnographic analysis of the narrative underscores how Serena's death affects both the mother and the father likewise. However, on one hand, we see Lucielia getting healed by Mattie Michael, the mother-figure of Brewster Place, while on the other hand, we see Eugene going to Chino, a gay prostitute, and seeking redemption for all the misdemeanours he assumes he has committed.

The next arresting narrative is of C.C. Baker's, through which Naylor meticulously portrays how African American males, stuck in the cobweb of an intimidating milieu, endeavour, though unsuccessfully, to construct their masculinity, manhood and individuality. In The Women of Brewster Place, Baker has been introduced as the chief of a terrorizing gang at Brewster Place, accountable for the horrendous rape of Lorraine. However, in The Men of Brewster Place, he has been revived as a male whose catastrophic petitions lie in his delusion of the self. His narrative further exemplifies how the intricate tethers of the domineering power structure forces a suppressed black male to justify his manhood on their terms, by transforming himself into a suppressor. A black autoethnographic examination of his narrative permits us to realize how Baker has been coerced to kill his own brother just for the sake of displaying his devotion towards the gang and justifying his masculinity and bravery. So, he is seen shutting his eyes and pressing the gun's trigger. Although Naylor describes Baker's deeds as something past salvation, yet she attempts to provide her dedicated readers a glance of the potential 
crisis in Baker's parenting which might have resulted in him getting transformed into a beast: "His parents stopped asking him long ago where he was going and why. He lies about the money he's bringing into the house - and they pretend to believe the lies because they need the help." (Naylor, The Men of Brewster Place 141) This also indicates how poverty as well as redundancy, which are also the possible constructs of the capitalist hegemonistic social order, add to the objectification and marginalization of the African American men, thereby, completely destroying their self-worth. Furthermore, Naylor, in one of her interviews with Virginia C. Fowler, adumbrates how this notion of masculinity and manhood is the construct of the mainstream hegemony, while justifying the significance of the rape scene in The Women of Brewster Place:

"I remember deliberately taking the narrative risk with that rape to stop the action...and to explain why that young man is raping her and to point the finger toward society and their definition of manhood. I wanted them to see that what's raping that woman, among other things, is society's conception of manhood, and their low evaluation of women. And no, I don't connect that at all to mothering, to how C.C. Baker was mothered. It was how he was taught he could be a man by society." (Fowler, "A Conversation with Gloria Naylor" 134-35)

These lines emphasize how Baker is driven by trepidation, rage, poverty, revolt, and his indefinable hunt for self-identity amidst the dogmatic conceptions of masculinity and manhood. The next striking narrative is of Abshu, Kiswana's boyfriend, who is a social activist, and the only male character who identifies this trivial place as a "site of resistance" (hooks, Yearning 148), and struggles to provide a better tomorrow to the inhabitants of Brewster Place. Just like Kiswana, to commemorate his African origin, he too re-names himself from Clifford Montgomery Jackson to Abshu, a more Africanized name. As an activist, Abshu commits himself to widen the spectrum of little African American children living on the streets without any guardian. His ultimate slogan becomes: "Lose no child to the street" (Naylor, The Men of Brewster Place 140). This is primarily because he too has been raised in a foster home, where there "weren't mean people, but they were stingy-stingy with their food and with their affection." (Naylor, The Men of Brewster Place 140). Here, black autoethnographic convictions allow us to apprehend how his stingy socioeconomic circumstances make him commit to himself that he would not allow any other African American kid to endure similar adversities as he did during his own childhood. As his narrative proceeds, we also see Abshu going against Reverend Moreland T. Woods, an avaricious as well as politically aspiring man who has "consciously betrayed the trust of the community" (Naylor, The Men of Brewster Place 144) by aiming to construct a new Sinai Baptist church, only to display and exercise his power over the innocent people. So, Abshu cleverly makes the whole black community actively participate in the tussle against this black-turned-white Woods. 


\section{CONCLUSION:}

In the novel, The Men of Brewster Place, although Naylor does not represent her black males possessing powerful communal bindings like what we find in her female characters in The Women of Brewster Place, yet she does display a black community with a barbershop at its heart. However, even this site of confrontation conditioned with an essence of brotherhood falls short in liberating these oppressed and victimized African American men, which becomes quite evident in Greasy's case whose ultimate inefficacious appeal, "I'm a man...I'm a man...", eventually making his suicide even more catastrophic.

To conclude, through the exemplary narrative matrix of the novel, the paper attempts to foreground the struggles of contemporary African American males- their psychologically, physiologically, economically as well as politically traumatized existences, conditioned with their limitations and disappointments- to highlight how they have also been victimized on the basis of race, class and sexuality. The paper also accentuates upon the fact that it is tremendously imperative to recognize black men's standpoint, to hear their side of the story, in order to completely accomplish black feminist standpoint, as it is through their quintessential accounts that we, as dedicated readers, finally understand how these black men are coerced to transform themselves from being a suppressed to being a suppressor, only to prove their manhood and masculinity to the mainstream hegemonistic power system.

\section{ACKNOWLEDGEMENT:}

The author owes a deep sense of appreciation and gratefulness to Dr. Anurag Kumar, Assistant Professor, SoLL, Shri Mata Vaishno Devi University, Dr. Amitabh Vikram Dwivedi, Assistant Professor, SoLL, Shri Mata Vaishno Devi University, Dr. Esha Malhotra, Head, SoLL, Shri Mata Vaishno Devi University, Dr. Ashu Vashisht, Principal and Associate Professor, GDC, Ramkot, Prof. Gurmail Singh, hon'ble Vice Chancellor, Akal University, Talwandi Sabo, Bathinda, and Dr. Shantanu Ghosh, Head, Department of English Studies, Akal University, Talwandi Sabo, Bathinda, for their stirring and scholarly assistance. Their continuous support and judicious guidance helped us to complete our paper.

\section{REFERENCES:}

C. Johnson C., and Jr., McCluskey, J. (1997). Black Men Speaking. Bloomington: Indiana University Press.

Delgado, R. and Stefancic, J. (1995). Minority Men, Misery, and the Marketplace of Ideas. Constructing Masculinity. Eds. M. Berger, B. Wallis and S. Watson. New York: Routledge. 211-220

Fowler, V. C. (2004) A Conversation with Gloria Naylor. Conversations with Gloria Naylor. Ed. Maxine Lavon Montgomery. Jackson: University Press of Mississippi. 123-37 
9 Bridging Black Male and Female Standpoints through Autoethnographic Cultural Symbiosis in Gloria Naylor's The Men of Brewster Place

Gayles, G. J. W. (1984). No Crystal Stair: Visions of Race and Sex in Black Women's Fiction. New York: Pilgrim Press.

hooks, b. (1990). Yearning: Race, Gender, and Cultural Politics. Boston, MA: South End Press. 148

Jackson, E. M. (1992). Images of Black Men in Black Women Writers 1950-1990. Indiana: Wyndham Hall Press.

Kannan, M. C. (2014) Gloria Naylor's The Men of Brewster Place- Not Just the Other Half, but an Exquisite Exploration of the Men's World. The Dawn Journal, Vol. 3, Issue 1. 788

Kumar, A. (2016). African American Literature: Politics of Marginal Space in the Fiction of Gloria Naylor. Atlantic Publishers and Distributors. 182

Montgomery, M. L. (2000) The Men of Brewster Place. - Review - book review. African American Review, Vol. 34, No. 1, Spring. 176-178

Naylor, G. (1998). The Men of Brewster Place. New York: Hyperion.

Naylor, G. (1983). The Women of Brewster Place, New York: Penguin Books.

Naylor, G. and Morrison, T. (1985). A Conversation. Southern Review21. 567-93.

(June 27, 2016). On Views of Race and Inequality, Blacks and Whites Are Worlds Apart. Pew Research Center.

Rich, A. (1981). Compulsory Heterosexuality and Lesbian Existence. London: Onlywomen Press.

Thomas, Jackie. (July 15, 2017). The Men of Brewster Place. - Review- book reviews. https://diverseeducation.com/article/8694/

\section{Author's Note}

Adishree Vats is an Assistant Professor of English at Department of English Studies, Akal University, Talwandi Sabo, Bathinda, India. Her area of expertise includes African American Literature, American Literature, Autoethnographic and Ethnographic Studies, Black Feminism, Standpoint Feminism, besides Travel Literature and Disability Studies. She has published various research papers, article reviews, book reviews and interviews of famous literary celebrities in SCOPUS, ESCI, SCIE, Web of Science, and other indexed journals. She has also qualified J\&K State Eligibility Test (JKSET) for Assistant Professor. 